\title{
Maritime Security and Deep Seabed beyond National Jurisdiction
}

\author{
Edwin Egede
}

\section{$\mathbf{1}$ Introduction}

The phrase, maritime security, has assumed prominence, mostly due to piratical acts off the coast of Somalia that had a serious impact on international sea trade in the Gulf of Aden, a critical trade corridor linking the Suez Canal and the Indian Ocean. ${ }^{1}$ Although maritime security is currently a widely used phrase, its exact scope is not very clear. From a focus on naval sea power, piracy and armed robbery at sea, there is increasingly an expansion of the scope of what falls within maritime security. However, relatively little has been articulated in the discourse on maritime security on its impact on the Deep Seabed beyond national jurisdiction (the Area), which under the United Nations Law of the Sea Convention (UNCLOS) 1982 is declared to be the Common Heritage of Mankind ( $\mathrm{CHM}$ ).

Yet the Area raises certain important maritime security issues such as the emplacement of weapons of mass destruction in the Area, prospects of piracy and terrorism against ships engaged in deep seabed mining (DSM) activities, as well as the challenge that DSM activities could actually raise issues as regard environmental security. Therefore, this chapter aims to investigate possible maritime security issues that may arise in the Area, engaging with what could be considered as a rather traditional state-centric maritime security approach (State/Military implications), as well as certain maritime security implications in the Area from a non-State centric perspective. The chapter begins by exploring the concept of maritime security as an unclear and expanding one (Section 2). Thereafter, it examines the notion of maritime security and the Area from a state-centric perspective (Section 3). Subsequently, it delves into maritime

1 This led to United Nations Security Council involvement. See Edwin Egede, 'Piracy and the East African Region' In Koutrakos, P. \& Skordas, A. (eds.) The Law and Practice of Piracy at Sea: European and International Perspectives. (Oxford and Portland, Oregon: Hart Publishing, 2014), pp. 249-265. 
security and the Area, engaging with it from a more non-state centric viewpoint (Section 4). The chapter ends with some concluding remarks (Section 5 ).

\section{Maritime Security - an Expanding Concept?}

Although maritime security has recently become a popular buzz phrase in international relations, ${ }^{2}$ the notion of maritime security does underpin a large chunk of the development of the law of the sea. ${ }^{3}$ For instance, the whole idea of the territorial sea and the so-called cannon shot rule of measuring this part of the sea was based on the security of the coastal State. ${ }^{4}$ In a similar way, the conception of freedom of navigation of the high seas was originally put forward by Grotius based on the economic ground of allowing the Dutch access to the high seas in order to partake in the highly lucrative East Indian trade; it was subsequently utilized to provide justification for big naval powers to patrol freely on the high seas displaying their sea power in their pursuit of security. ${ }^{5}$ Furthermore, the age long understanding of pirates as 'enemies of the human race $^{\prime} 6$ with all States having universal jurisdiction, depicts that maritime security has always been an intrinsic part of the law of the sea. What, arguably, is novel about the growing notion of maritime security in the law of the sea is the increasing shift from focusing mainly on States actors to an increasing highprofile engagement with non-state actors, including organizations, such as the International Maritime Organization (IMO); private maritime security companies; the perpetrators of maritime security crimes, such as pirates and armed robbers at sea, private fishing trawlers engaged in Illegal, Unreported and Unregulated (IUU) fishing, terrorists groups carrying out their dastardly acts at sea and gangs involved in illegal trafficking of people by sea; as well as human security aspects focused on the rights of victims of maritime crimes, such as seafarers and hostages held by pirates for ransom, as well as vulnerable

2 C. Bueger, 'What is maritime security?' (2015) 53 Marine Policy, 159-164 at 159.

3 However, it must concede that the phrase, 'maritime security', was not until recently a vocabulary used in the law of the sea. For instance, the phrase 'maritime security' to the knowledge of this author was not used during the Third United Nations Conference on the Law of the Sea (UNCLOS III) negotiations, neither is it mentioned in the Law of the Sea Convention (LOSC) 1982.

4 W.L. Walker, 'Territorial Waters: the Cannon-Shot Rule,' (1945) 22 British Yearbook of International Law, 210-231.

5 T. Scovazzi, 'The Evolution of International Law of the Sea: New Issues, New Challenges', (2001) 289 Recueil des Cours, 39-243.

6 Le Louis case (1817) 2 Dods at 210. 
migrants at sea. Theoretically, this could be regarded as a swing from a purely realist perspective focusing solely on States to a more liberalist position that recognizes that international relations must necessarily also engage with nonState actors as well. ${ }^{7}$ However, it must be pointed out that even in cases when maritime security engages with non-State actors, there still remains a key role for State actors to play, in taking enforcement actions and countering maritime (in)security arising from threats of such non-State actors. ${ }^{8}$ They can do so through agencies such as the navy and the coast guards.

Klein points out that " $t]$ he term "maritime security" has different meanings depending on who is using the term or in what context it is being used. ${ }^{9}$ In her opinion, it may best be understood from two key aspects, namely, traditional security concerns and responses to perceived maritime security threats. The former, she states, primarily refers to border protection, involving preventing incursions into areas that are considered as the sovereign domain of a State. It also refers to power projections, involving a State exercising naval military power in its relationship with other States. The latter, on the other hand, reflects certain steps taken by States to reduce the risk of certain crimes or activities which they believe would prejudice or injure their interests and society. ${ }^{10}$ Klein then provides a definition of maritime security as 'the protection of a State's land and maritime territory, infrastructure, economy, environment, and society from certain harmful acts occurring at sea."11 This definition is rather restrictive because it appears to over-emphasize more on the interest of the State and deemphasizes engagement with the interests of non-State actors, including international organizations, private companies and individuals, as regards maritime security.

A. Slaughter, 'A Liberal Theory of International Law' (2000) 94 American Society of International Law Proceedings, 240-248.

8 This is not to say that non-State actors, such as private security companies, do not play a role in countering maritime security threats and challenging the monopoly of States in this regard. See: Carolin Liss, 'New Actors and the State: Addressing Maritime Security Threats in Southeast Asia,' (2013) 35(2) Contemporary Southeast Asia, pp. 141-162; and Elke Krahmann, 'From State to Non-State Actors: The Emergence of Security Governance' in Elke Krahmann (ed.), New Threats and New Actors in International Security, (2005, United States of America, Palgrave Macmillan), pp. 3-19.

9 N. Klein, Maritime Security and the Law of the Sea (2011, Oxford: Oxford University Press) at 4.

10 N. Klein, 'Maritime Security' in D.R. Rothwell, A.G., Elferink Oude, K.N.Scott, and T. Stephens (eds), The Oxford Handbook of the Law of the Sea, (Oxford University Press, Oxford, 2015) at pp. $5^{82-583}$.

11 Ibid at 583 . 
The recently adopted African Charter on Maritime Security and Safety and Development in Africa (Lomé Charter) defines maritime security for the purposes of the Charter as: 'the prevention of and fight against all acts or threats of illicit acts against a ship, its crew and its passengers or against the port facilities, maritime infrastructure, maritime facilities and maritime environment.'12 Again, this definition appears to be rather limited as it does not focus on maritime security issues that arise from State to State tensions, such as age-long conflicts between the navies of different States and clashes that may arise from maritime delimitation disputes.

Another example of definition of the concept of maritime security, this time in the national context, is the one of the UK National Strategy for Maritime Security, which states that it is: 'The advancement and protection of the UK's national interests, at home and abroad, through the active management of risks and opportunities in and from the maritime domain, in order to strengthen and extend the UK's prosperity, security and resilience and to help shape a stable world. ${ }^{13}$ This rather broad and vague definition is wide-ranging enough to cover virtually every threat arising from the maritime domain. It is also not very clear what 'the active management of risks and opportunities' is in practice and which tools would be used to implement this management.

Bueger, in an interesting article interrogating the meaning of maritime security, ${ }^{14}$ concludes that it:

$[\ldots]$ has no definite meaning. It achieves its meaning by actors relating the concept to others, by attempts to fill it with different issues and by acting in the name of it. If actors agree on the value of maritime security in general terms, its practical meaning will always vary across actors, time and space. Striving for a universally acceptable definition of maritime security is hence an unproductive quest. ${ }^{15}$

12 Art.1(1). The Lomé Charter was adopted as a binding treaty by 30 African States on 15 October 2016 at the African Union Extraordinary Summit at Lomé, Togo. The Lomé Charter is available at: http://www.african-union-togo2015.com/en/accueil.

13 UK National Strategy for Maritime Security, May 2014 at 15, https://www.gov.uk/govern ment/uploads/system/uploads/attachment_data/file/310323/National_Strategy_for_ Maritime_Security_2014.pdf.

14 Bueger, op.cit. at pp. 160-163 explored the meaning of maritime security using three frameworks: a semiotic viewpoint of seeking to grasp its meaning by exploring its relations with other terms; a constructivist securitization framework and the actual practice of relevant actors.

Bueger, op.cit. at 163 . 
Then again, Germond introduces a geo-political dimension to the exploration of maritime security and points out that: 'Maritime security has to do with (illegal and disruptive) human activities in the maritime milieu, that is to say a certain geographically delimited space. Thus, states are differently impacted by maritime security threats depending on their actual geographical location.' ${ }^{16}$ Thus, one could rephrase the renowned statement of the eminent constructivist, Wendt, that: 'maritime security is simply what States make of it!'17 Although, there is no 'one size fits all' definition of maritime security various intergovernmental organizations and States have adopted strategies or non-binding Codes to deal with maritime security threats. ${ }^{18}$ More recently, the African Union has even adopted a binding treaty on maritime security. ${ }^{19}$

In essence, since the exact scope of the concept of maritime security is highly contested, there is nothing that forecloses its application to the Area because there is a real possibility of 'illegal and disruptive human activities', ${ }^{20}$ amounting to a threat to security, occurring as regard the Area. This is further supported by the requirement under the 1982 United Nations Convention on Law of the Sea (LOSC) that the Area be used for peaceful purposes only, especially since peace generally in international relations is used along with the

16 B. Germond. 'The geopolitical dimension of maritime security' (2015) 54 Marine Policy, $137-142$ at 138.

17 A. Wendt, 'Anarchy is what States Make of it: The Social Construction of Power Politics' (1992) 46 International Organization, 391-425.

18 See, for example: the 'European Union Maritime Security Strategy: Responding Together to Global Challenges: A Guide for Stakeholders' (EUMSS), Council of the EU, 24 June 2014, and its Action Plan of 16 December 2014, as revised on 26 June 2018; NATo Alliance Maritime Strategy 2011, http://www.nato.int/cps/en/natohq/official_texts_75615.htm; African Union's 2050 Africa's Integrated Maritime Strategy 2014, http://pages.au.int/mari time/documents/2050-aim-strategy-o ; the US National Strategy for Maritime Security, September 2005, http://www.state.gov/documents/organization/255380.pdf; US AsiaPacific Maritime Strategy 2015, http://www.defense.gov/Portals/1/Documents/pubs/ND AA\%20A-P_Maritime_SecuritY_Strategy-08142015-1300-FINALFORMAT.PDF; and UK National Strategy for Maritime Security 2014. For non-binding Codes, see the following IMO inspired agreements: The Regional Cooperation Agreement on Combating Piracy and Armed Robbery against Ships in Asia (ReCAAP), 2004; the Code of Conduct concerning the Repression of Piracy and Armed Robbery against Ships in the Western Indian Ocean and the Gulf of Aden (Djibouti Code of Conduct), 2009 as revised by the Jeddah Amendment 2017; and the Code of Conduct Concerning the Repression of Piracy, Armed Robbery Against Ships, and Illicit Maritime Activity in West and Central Africa (the Yaoundé Code of Conduct, 2013, http://www.imo.org/en/OurWork/Security/WestAfrica/ Documents/code_of_conduct\%2osigned\%2ofrom\%2oECOWAS\%2osite.pdf.

19 See note 12 above.

$20 \quad$ Germond, op.cit at 138. 
notion of security. ${ }^{21}$ Recently, the International Seabed Authority (ISA) has acknowledged the need to consider maritime security in the Area in the Draft Regulations on Exploitation of the Minerals Resources in the Area, where it requires operators applying for a plan of work to exploit to also include, amongst other things, a health, safety and maritime security plan along with their application. ${ }^{22}$

\section{Maritime Security and the Area: a State-Centric Focus}

\subsection{Area, Peaceful Purposes and Military Activities: a Matter of Definition}

One of the crucial points raised in Arvid Pardo's renowned address to the United Nations General Assembly in 1967 , of the need to establish a regime for the exploitation of the resources of the Area, was that activities in this part of the sea should take place in a 'peaceful atmosphere'. He stressed the rising concern that the Area could '... progressively and competitively [be] appropriated, exploited and used for military purposes by those who possess the

21 See for instance Articles 1(1) and 24(1) of the United Nations Charter which state that the Purposes of the United Nations are:To maintain international peace and security, and to that end: to take effective collective measures for the prevention and removal of threats to the peace, and for the suppression of acts of aggression or other breaches of the peace, and to bring about by peaceful means, and in conformity with the principles of justice and international law, adjustment or settlement of international disputes or situations which might lead to a breach of the peace' and 'In order to ensure prompt and effective action by the United Nations, its Members confer on the Security Council primary responsibility for the maintenance of international peace and security, and agree that in carrying out its duties under this responsibility the Security Council acts on their behalf.

Article 1 of NATO treaty states that: 'The Parties undertake, as set forth in the Charter of the United Nations, to settle any international dispute in which they may be involved by peaceful means in such a manner that international peace and security and justice are not endangered, and to refrain in their international relations from the threat or use of force in any manner inconsistent with the purposes of the United Nations.'

Article $3(f)$ of the African Union Constitutive Act states: 'The objectives of the Union shall be to ... promote peace, security, and stability on the continent.'

22 See Draft Regulations on Exploitation of Mineral Resources in the Area: Prepared by the Legal and Technical Commission, ISBA/24/LTC/WP.1/Rev.1 of 9 July 2018, Draft Regulation 7(3)(f). Annex IV of this Draft Regulations on the nature of the Health, Safety and Maritime Security Plan has not been developed and the annex states as follows: '[To be populated following discussion with the IMO Secretariat, members of the Authority and Stakeholders].' 
required technology.23 This celebrated address, which called for this part of the sea to be declared as the Common Heritage of Mankind, acted as a trigger for the third United Nations Conference on the Law of the Sea (UNCLOS III) that eventually culminated in the adoption and the eventual coming into force of the LOSC 1982. The Convention requires that: 'The Area shall be open to use exclusively for peaceful purposes by all States, whether coastal or land-locked, without discrimination and without prejudice to the other provisions of this Part.'24 The phrase 'use exclusively for peaceful purposes' was not defined by the Convention. This therefore raises the issue of whether the peaceful purposes provisions of LOSC completely prohibit all military activities.

The scope of military activities must here be examined. According to Wolfrum, virtually all military activities at sea would fall under at least one of the following activities:

1. Navigation on the water surface or in the water column including all military activities connected with navigation.

Navigation and connected activities are performed as routine marine operations or periodic conditioned manoeuvres. They may serve one or more of the following purposes: exercising of ships, co-operation between navy, air force and land forces of one or more nationalities, the latter adding a further co-operation aspect (e.g. Ocean Venture 1981), control of the sea, projection of naval presence (e.g. the presence of US units in the vicinity of the Persian Gulf) and deterrence;

2. Emplacement of sea-based missiles for strategic purposes. This activity is presently fulfilled (mainly) by missile launching nuclear submarines; 3. The emplacement of sea-based surveillance devices such as fixed acoustic detection systems;

4. The emplacement of sea-bed based weapons systems for strategic or tactical purposes such as magnetic or acoustic mines against surface ships or submarines. Furthermore, the emplacement of strategic missiles on the seabed has been discussed;

5. The emplacement of sea-bed based surveillance devices like the fixed acoustic detection array systems which according to some sources have been deployed along the east and west coast of the United States and some strategically important points in the oceans;

23 Para 5 of UN General Assembly 22nd Session, Official Records of Fifth Committee, 1515th Meeting, 1 November 1967 (Arvid Pardo, the Maltese Ambassador to the UN) http://www. un.org/depts/los/convention_agreements/texts/pardo_garg67.pdf. 
6. Military research including the testing of weapons, conducted either on the water surface, in the water column, or the subjacent seabed and subsoil. 25

It is doubtful that the list above could be regarded as a completely exhaustive list of what constitutes 'military activities.'

Recently, an arbitral tribunal has had the occasion to give its interpretation of the definition of military activities. The Arbitral Tribunal in the South China Sea Arbitration (Merits) between the Republic of the Philippines and the People's Republic of China, ${ }^{26}$ in seeking to determine whether it had jurisdiction over the case, had to ascertain if the Chinese activities in the South China Sea were military in nature. The latter issue was reserved from its previous award on jurisdiction and admissibility. ${ }^{27}$ The Tribunal was, however, quick to point out that its remit was merely to consider Article 298(1)(b), which applies to "disputes concerning military activities" and not to "military activities" as such.' In its view, the relevant question was to consider whether 'the dispute itself concerns military activities, rather than whether a party has employed its military in some manner in relation to the dispute. ${ }^{28}$

Nonetheless, the decision of the Tribunal in this regard raises some stimulating ideas that could provide some guidance on what are military activities. For instance, the Tribunal points out that what represents a 'quintessentially military situation' is a state-centric conflict that involves the military forces of one State (i.e. Philippines) against a combination of military and paramilitary forces of another State (i.e. China) 'arrayed in opposition to one another.'29 Furthermore, the Tribunal, in determining that certain Chinese activities

25 Wolfrum, R., "Restricting the Use of the Sea to Peaceful Purposes: Demilitarization in Being?" (1981) 24 German Yearbook of International Law p. 200 at 205-6.

26 In the matter of the South China Sea Arbitration before an arbitral tribunal constituted under Annex VII to the 1982 United Nations Convention on the Law of the Sea between the Republic of The Philippines and The People's Republic of China, PCA Case No 2013-19 of 12 July 2016. Available at: <http://www.pcacases.com/pcadocs/PH-CN\%20-\%20201 $60712 \% 20-\% 20$ Award.pdf>

27 Art. 298(1)(b) of LosC allows State Parties to exclude by way of declaration the compulsory jurisdiction under the treaty in 'disputes concerning military activities, including military activities by government vessels and aircraft engaged in non-commercial service, and disputes concerning law enforcement activities in regard to the exercise of sovereign rights or jurisdiction excluded from the jurisdiction of a court or tribunal ...' By declaration dated 25 August 2006, China had triggered all of these exceptions listed in Art. 298, including the 'military activities' exception. See Para.161 of PCA Case No. 2013-19 of 12 July 2016 and also the award on jurisdiction and admissibility of 29 October 2015.

28 Para.1158 of PCA Case No. 2013-19 of 12 July 2016.

29 Ibid, para.1161. 
were not military in nature, was happy to rely on China's repeated statements and position that the activities were primarily, if not wholly, for civilian use. ${ }^{30}$ Ostensibly, this could appear to suggest that a State may solely decide on whether or not their activities at sea is military in nature. However, when this position is read along with the opinion of the Tribunal that it was not determining military activities, as such, but merely seeking to decide on whether Article 298(1)(b) was applicable to the arbitration, it becomes clearer that the Tribunal was merely taking the position that China ought to be estopped from relying on the exclusionary provisions of the Article. China had consistently declared that such activities were civilian and not military.

Clearly military activities would involve military confrontation between two or more states. However, it is clear that it goes beyond this as could be seen from the rather long, but obviously not exhaustive list, of possible military activities at sea provided, as quoted earlier, by Wolfrum. ${ }^{31}$

\subsection{Are All Military Activities in the Area a Security Threat?}

Yet the question arises as to whether all military activities in the Area constitute a breach of the peace thereby raising maritime (in) security concerns. Various States have interpreted this differently to suit their national interests. Certain States, especially developed States with nuclear capacity, interpret this provision as merely prohibiting military activities that has an aggressive purpose. These States argue that this provision would only prohibits military activities that are inconsistent with the United Nations Charter and other obligations under international law, which is what would create maritime (in)security. ${ }^{32}$ In support of this viewpoint it has been stated that Article 141, as well as other provisions related to use of the ocean for peaceful purposes, ${ }^{33}$ should be interpreted in the light of Article 301 which states: 'In exercising their rights and performing their duties under this Convention, States Parties shall refrain from any threat or use of force against the territorial integrity or political independence of any State, or in any other manner inconsistent with the principles

3о Ibid, paras.925-938, 1024-1028 and 1164 .

31 See note 25 above.

32 See M. Nordquist (ed.), United Nations Convention on the Law of the Sea $1982-A$ Commentary, Vol III (Martinus Nijhoff, Dordrecht, 1995), pp. 90-91; E. Egede Africa and the Deep Seabed Regime: Politics and International Law of the Common Heritage of Mankind (Springer, Heidelberg, 2011), pp. 79-80; J Kraska and R. Pedrozo, International Maritime Security Law, (Martinus Nijhoff, Leiden, 2013) at pp. 304-309 and M. Lodge, 'The Deep Seabed' and J. Kraska, 'Military Operations' in D.R. Rothwell, A.G. Oude Elferink, K.N. Scott, and T. Stephens, (eds), The Oxford Handbook of the Law of the Sea, (Oxford University Press, Oxford, 2015) at 230 and 868-869 respectively.

See Articles 88, 143(1), 147(2)(d), 155(2), 240(a), 242(1) and 246(3) of LOSC 1982. 
of international law embodied in the Charter of the United Nations. ${ }^{34}$ The United States of America is an example of a State that adopts this viewpoint. In a commentary which accompanied the transmittal by the President of the LOSC 1982, President Clinton stated:

In furtherance of this principle, article 141 declares the Area to be open to use by all States. Only mining activities are subject to regulation by the International Seabed Authority [...]. Other activities on the deep seabed, including military activities, telecommunications and marine scientific research, may be conducted freely in accordance with principles of the Convention pertaining to the high seas, including the duty to have reasonable regard to other uses. ${ }^{35}$

In addition, the commentary points out that none of the LOsc provisions on 'peaceful purposes' and 'peaceful use' where intended to create new rights or obligations nor impose restraints upon military operations, or impair the inherent right of self-defense, and so long as the military activities are consistent with the principles of international law they were not prohibited by international law generally and the LosC in particular. ${ }^{36}$ Kraska and Pedrozo further cite a 1985 United Nations Secretary-General's Report, which concluded military activities that were consistent with the provisions of Article 2(4) and Article $5^{1}$ are not prohibited by the Losc. ${ }^{37}$ It would appear that from this standpoint military activities are not prohibited by the LOSC in the Area in the following instances: first, if they do not amount to a threat or use of force against the territorial integrity or political independence of any state, or in any other manner inconsistent with the purposes of the United Nations; second, if the activities are a valid exercise of the right to self-defense or if such activities amounting to the threat or use of force is done with the authorisation of the Security Council; third, if it is not expressly prohibited by a conventional or customary international law norm.

On the other hand, for certain other States, the peaceful purposes provision in Part XI of the LOSC, connotes that all military activities in the Area

34 Although Art.301 uses the phrase 'peaceful uses' instead of 'peaceful purposes' it has been pointed out that these two phrases are synonymous. See Kraska and Pedrozo, International Maritime Security Law, op.cit. at pp. 305-306 citing the Virginia Commentary. http://www.foreign.senate.gov/imo/media/doc/treaty_103-39.pdf.

$36 \quad$ Ibid at p. 94.

37 Kraska and Pedrozo, International Maritime Security Law at 307. 
are strictly prohibited. ${ }^{38}$ For instance, the then Organisation for African Unity (OAU) captured this position by stressing that the Area 'should be used exclusively for peaceful purposes [and] [a]ny utilisation of this zone for military purposes is strictly prohibited. ${ }^{39}$

Francioni, points out that a minority of scholars support the latter view. Using the analogy of certain other treaties it has been argued that there is an absolute prohibition of military activities. ${ }^{40}$ For instance, the Antarctica Treaty 1959 in Article 1 titled - Peaceful Purposes - states that:

1. Antarctica shall be used for peaceful purposes only. There shall be prohibited, inter alia, any measure of a military nature, such as the establishment of military bases and fortifications, the carrying out of military manoeuvres, as well as the testing of any type of weapon.

2. The present Treaty shall not prevent the use of military personnel or equipment for scientific research or for any other peaceful purpose.

Francioni points out that early negotiations in the UNCLOS III were based upon a generally prevalent view that the seabed which is the common heritage of mankind was to be completely demilitarized as it was meant to be used for peaceful purposes only. ${ }^{41}$ However, a close examination of the relatively detailed provisions of the Antarctica Treaty, in comparison with the provisions of the LOSC on peaceful purposes, would appear to indicate that the LOSC did not intend to prohibit all military activities. While the Antarctica Treaty specifically and explicitly prohibits 'any measure of a military nature', the provision of the LOsC does not explicitly indicate such prohibition.

Conversely, one could criticize those States and scholars that claim that certain military activities may take place in the Area for erroneously conflating the provisions on peaceful purposes in Article 88 (high seas) with that of Article 141(the Area). In doing so, they would wrongly interpret the two

38 See for instance, the Resolution of the Council of Ministers of the Organization of African Unity on the International Zone extending beyond National Jurisdiction, DOC/A/ CONF.62/50 of 14 September 1976.

39 Doc.A/CONF.62/50 of 14 September 1976 referred to in UNCLOS III Official Records Vol VI, p. 121.

40 See for instance, Antarctic Treaty 1959, Art.1 and Treaty on Principles Governing the Activities of States in the Exploration and Use of Outer Space, including the Moon and Other Celestial Bodies, Art. Iv. See Francesco Francioni, 'Peacetime use of Force, Military Activities, and the New Law of the Sea, (1985) 18(2) Cornell International Law Journal, p. 203 at $221-225$.

41 Ibid at 223-224. See Art.141 of LOSC. 
provisions in an identical way. ${ }^{42}$ First, the two provisions have different wordings, while Article 88 states that the high seas would be 'reserved for peaceful purposes', Article 141 states that the Area should be used 'exclusively for peaceful purposes.' Second, the provisions apply in essence to two different regimes having two different applicable principles: for the high seas, res communis; and for the Area, common heritage of mankind. It would be recalled that Article 141 points out that the peaceful purposes must be in line with the relevant part of the Convention. Whilst the peaceful purposes as used under Article 88 is compatible with military activities, especially with the long historical connection with such military activities and the whole notion of the freedoms of the sea, it is not so with the common heritage of mankind. The latter principle, which is a relatively recent one, is premised mainly around resource exploitation of this part of the sea, a core activity that is not necessarily reconcilable with military activities.

An interesting practical example, of the conundrums that may arise from these divergent views on the peaceful use of the Area is with regard to manned subsea 'space station' that could be used not only for civilian, but also for military purposes, such as surveillance through, for instance, having sensors to detect the submarines of other States. ${ }^{43}$ This raises two interesting issues.

First, whether the use of such mixed-use (or hybrid) installations or structures in the Area would be regarded as military activity. Although, the question of the mixed-use of installations or structures was raised by the Philippines in its arguments in the South China Seas arbitration in relation to whether China's island building activities fell within the ambit of military activities under Article 298(1)(b) of LOSC, the Tribunal did not directly engage with this point. ${ }^{44}$ In this author's view, two possible approaches may be adopted to determine this - the initial or original purpose and predominant use approaches. The former focuses on the initial or original purpose for setting up the installation or structure. If such was for civilian purpose then it could be arguably regarded as being used for non-military activities, while if such was originally constructed for a military purpose then it could perhaps be regarded as used for military activities. However, this may raise complexities when such submersible structure or installation though initially set up for civilian purposes is subsequently

42 See Isaak I. Dore, "International Law and the Preservation of the Ocean Space and Outer Space as Zones of Peace: Progress and Problems" (1982)15(1) Cornell International Law Journal, pp. 1-61 at 21-22.

See 'China is Planning a Massive sea lab 10,000 feet underwater', Bloomberg, June 8, 2016, http://www.bloomberg.com/news/articles/2016-o6-07/china-pushes-plan -for-oceanic-space-station-in-south-china-sea.

Paras. 893 and 1013-1014, PCA Case No .2013-19 of 12 July 2016. 
predominantly used for military purposes. The predominant use approach would probably be a better approach. Here the predominant and prevalent use of the installations or structures would determine whether such installation or structures should be characterized as being used for military activities or not.

Another issue is whether the use of such submersible installations or structures should be regarded as amounting to allowable military activity in the Area. Obviously, as indicated above, States that argue that the peaceful use clause does not prohibit all military activities would take the position that such non-aggressive use of the Area would amount to allowable military activity. According to Treves:

... listening and other detection or communication devices are considered more acceptable than weapons. Weapons are inherently dangerous, while detection devices are considered more acceptable than weapons. Weapons are inherently dangerous, while detection and communications devices are not. This judgement will probably have some bearings on the solution of conflicts among different uses of the seabed. It seems easier to accommodate the emplacement of detection or communication devices to other uses, such as those related to resources, than the emplacement of weapons. ${ }^{45}$

On the other hand, those who argue that all military activities are prohibited in the Area would obviously take the view that, as long as such activity may be categorised as a military one, it is not allowable in the Area.

\subsection{The Area and the Seabed Arms Control Treaty 1971}

The paramount security concern in the Area is the prospect of emplacement of Nuclear Weapons and other Weapons of Mass Destruction in the seabed, ocean floor and subsoil of the Area. As far back as 1971, prior to LOSC, the Treaty on the Prohibition of the Emplacement of Nuclear Weapons and other Weapons of Mass Destruction on the Seabed and the Ocean Floor and in the Subsoil thereof (the Seabed Arms Control Treaty) was adopted to deal with this issue. ${ }^{46}$ This treaty, which has been described as an example of 'superpower

45 Tullio Treves, "Military Installations, Structures, and Devices on the Seabed", (1980) 74(4) American Journal of International Law, pp. 808-857 at 809-810.

46 This treaty of 10 Articles was adopted by a large number of States, (104 in favour, 2 against and 2 abstentions) on February 11, 1971 and came into force on May 18, 1972. So far 94 States have become States Parties. Only France out of the P-5 members of the UNSC is not a Party. See http://www.state.gov/t/isn/5187.htm. 
symbiosis, ${ }^{47}$ arose from a strictly Statist concern about maritime security concerning the Area. The key concern was the possibility of States, especially the big powers, utilising the Area as another venue for furthering their nuclear arms race. This concern was not far-fetched, especially since during the Cold War there was intense nuclear competition between the bipolar powers the USA and the then Union of Soviet Socialist Republics (USSR), along with their respective allies.

The Convention, which is still in force, prohibits the emplanting or emplacing of any nuclear weapons or other types of weapons of mass destruction, as well as structures, launching installations or any other facilities specifically designed for storing, testing or using such weapons on the seabed, ocean floor and the subsoil thereof beyond the outer limits of the territorial seas (which of course would include the Area). ${ }^{48}$ The Treaty makes provision for verification through the observation by State Parties of the activities of other States Parties, provided that observation by the former does not interfere with the lawful activities of the latter. ${ }^{49}$ If after such observations there are still doubts as to whether the obligations under the Treaty are being carried out, the State Party carrying out the observations and the other one carrying out the activities giving rise to the doubts are required to consult together with a view to removing the doubts. If, however, the uncertainty still persists, the State Party having the doubts is required to notify the other States Parties to the Treaty, who are to cooperate on further procedures for verification, as they may agree, including the appropriate inspection of objects, structures, installations or other facilities that reasonably may be expected to be in breach of Article 1 of the Treaty. The State Parties located in the region of the activities, including any coastal State, and any other Party so requesting, are also entitled to participate in such consultation and cooperation. After completion of the further procedures for verification, an appropriate report is required to be circulated to other State Parties by the Party that initiated such procedures. ${ }^{50}$

The Treaty also makes provision for situations where the State responsible for the activities that raise doubt cannot be easily identifiable. Here, in the case of the initial step of consultations, the State having doubts is to notify and

47 See James Barry Jr., "The Seabed Arms Control Issue 1967-1971 A Superpower Symbiosis" in Richard B. Lillich \& John Norton Moore(eds.), Role of International Law and an Evolving Ocean Law, (Newport, 1980), pp. 572-585 at 573, where this phrase was used and described as 'a relationship in which advanced States with divergent goals temporarily join forces to achieve a specific end.'

48 See Arts. I and II.

49 Art. III(1).

$50 \quad \operatorname{Art} \operatorname{III}(2)$. 
make appropriate enquiries with State Parties in the region where the activities has taken place or from any of the other State Parties. If the identity of such State responsible for the activities cannot be ascertained through these inquiries, the inquiring State Party may undertake further verification procedures, including inspection, and shall invite the participation of the State Parties in the region where the activities is taking place, including any coastal State, and any other Party desiring to cooperate. ${ }^{51}$ In the event that the consultation and verification process fails to clarify the doubt and there are still serious questions concerning the fulfilment of obligation under the treaty, the State Parties may refer the matter to the United Nations Security Council, who may take action in line with its primary responsibility to maintain peace and security under the UN Charter. ${ }^{52}$

There are, however, some criticisms of the Seabed Arms Treaty. For one, although there are currently a huge number of States Parties to the Treaty, ${ }^{53}$ including a number of nuclear weapons States, some known nuclear weapons States, such as France, Pakistan, Israel and North Korea, are yet to become Parties to this important Treaty framework. Another problematic area of the Convention is the escape clause whereby States Parties may withdraw from the Treaty in the following instance:

Each State Party to this Treaty shall in exercising its national sovereignty have the right to withdraw from this Treaty if it decides that extraordinary events related to the subject matter of this Treaty have jeopardized the supreme interests of its country. It shall give notice of such withdrawal to all other States Parties to the Treaty and to the United Nations Security Council three months in advance. Such notice shall include a statement of the extraordinary events it considers to have jeopardized its supreme interests. ${ }^{54}$

The ground for withdrawal is rather vague and subjective. Furthermore, the requirement that the Party which seeks to withdraw merely gives three monthsnotice to other States Parties and the Security Council is rather problematic. This appears to be a rather short notice period for such a significant issue as this. The 2003 withdrawal of North Korea from the Nuclear Nonproliferation

\footnotetext{
$51 \quad \operatorname{Art}$ III (3).

52 Art. III (4).

53 See note 42 above for the number of Parties to the Treaty.

54 Art. IV.
} 
Treaty, with similar provision, ${ }^{55}$ is instructive of the challenge with this provision. Obviously, when a State Party withdraws from the Treaty it would be res inter alios acta in relation to such State. However, States who are outside the Seabed Arms Control Treaty framework could only be bound by the obligation prohibiting the emplacement or emplantment of nuclear weapons and WMD in the seabed beyond the territorial sea if it could be argued that this norm has crystallised into Customary International Law. ${ }^{56}$

Another criticism is that the Treaty does not prohibit mobile installations such as a nuclear submarine resting at the bottom of the sea or the deployment of 'crawlers' and also mobile missile platform that may move along the ocean. ${ }^{57}$ The ambiguity of the Treaty is also reflected in the reference to structures and installations 'specifically designed for storing, testing or using' WMD, which gives the almost absurd indication that the ban depends on its initial design and not its purpose. ${ }^{58}$ Furthermore, the Treaty, for obvious reasons is limited to nuclear weapons, as well as other types of WMDs, but does not really ban nuclear devices to be used for 'peaceful' purposes. ${ }^{59}$ It thus does not cover the possibility of nuclear disasters of a scale such as the Chernobyl and Fukushima disasters that may arise from such 'peaceful' use of nuclear materials in the Area, which may have environmental implications and raise issues of environmental (in) security through the actions of States. ${ }^{60}$

What is clear, is that the Seabed Arms Treaty although it seeks to put in place some control over the use of nuclear weapons in the seabed, including the Area, does not effectively denuclearize the seabed, and neither does it create some type of nuclear weapons free zone in the Area. ${ }^{61}$ Of course, another major gap of this rather dated Seabed Control Treaty is that it does not cover non-state actors, notably terrorist groups, which this chapter would discuss further in section 4 below.

55 See Art. $x$ of the Nuclear Non-Proliferation Treaty.

56 See North Sea Continental Shelf Cases ICJ Rep.1969, p. 3 at 41-44; Case Concerning Military and Paramilitary Activities in and Against Nicaragua (Merits) ICJ Rep.1986, p. 14 at 98 .

57 See Barry Jr., 'The Seabed Arms Control Issue 1967-1971 A Superpower Symbiosis', supra at p. 583 and Dore, 'International Law and the Preservation of the Ocean Space and Outer Space as Zones of Peace: Progress and Problems', supra at 15.

58 See Art. 1 and Dore, Ibid at pp. $15^{-16}$.

59 Dore, ibid at p. 13 .

6o See below section on non-State centric approach for more discourse on environmental security.

61 For nuclear Free Zones in the World see https://www.un.org/disarmament/wmd/nuclear/ nwfz/. 


\subsection{Maritime Security and Prospect of Inter-State Tensions over Mining Sites in the Area}

Another key maritime security issue from a State-centric approach is the risk of inter-State tensions over maritime mining sites, which may escalate into conflicts. This threat is reduced in the case of deep seabed mining (DSM) activities due to the crucial role of the International Seabed Authority (ISA) as the intergovernmental organization vested under the LOsc to act on behalf of mankind and who is in charge of allocating mining sites in the Area. ${ }^{62}$

However, a scholar had pointed out that '[a]lthough the International Seabed Authority has shouldered the responsibility for managing the activities on the International seabed beyond national jurisdiction, future exploration is sure to raise many jurisdictional challenges akin to fossil fuel resources, and some claims and counterclaims regarding certain areas can be expected.' ${ }^{63}$ Kraska, in an interesting article on Indian Ocean Security, ${ }^{64}$ provides the example of India's security concerns, as regards the allocation by the ISA to China, its regional rival, (via the China Ocean Mineral Resources Research and Development Association [COMRA], a State owned entity), of mining site in the Southwest Indian Ocean for the exploration of polymetallic sulphide ore deposit. ${ }^{65} \mathrm{He}$ points out that this was unsettling for India and states that:

New Delhi fears it will provide China with "an excuse to operate their warships in [the] area." The Directorate of Naval Intelligence in New Delhi warns that the seabed mining development gives China a reason to "maintain a continuous presence" in the central Indian Ocean. The Ministry of External Affairs called the Chinese seabed mining plan a "worrying development."66

This does indicate a potential for State to State tensions over allocation of mining sites for DSM. For instance, India in its recent Maritime Security Strategy 2015 also mentioned its DSM activities in the Indian Ocean as one of its overseas

62 See $\operatorname{Arts.137(2)}$ and (3), 153(2)-(6), 157(1) and 162(2)(j)-(1). See Chapter 7 of this book, J. Dingwall, 'Commercial Mining Activities in the Deep Seabed Beyond National Jurisdiction: The International Legal Framework.'

63 Nirmal Verna, 'India and Transnational Maritime Challenges' in Mohan Malik, Maritime Security in Indo-Pacific Perspectives from China, India and the United States of America, (Bowman \& Littlefield, London, 2014), pp. 209-214 at 211.

64 James Kraska, 'Indian Ocean Security and the Law of the Sea', (2012) 43 Georgetown Journal of International Law, pp. 434-493, especially at 459-462.

65 Exploration Contract began November 18, 2011 and to end November 17, 2026. See https:// www.isa.org.jm/deep-seabed-minerals-contractors.

66 Kraska, op.cit at p. 461. 
maritime investments that need to be secured. ${ }^{67}$ Furthermore, Japan in its National Security Strategy, under the heading '[r]isks to Global Commons,' which it identifies as one of its national security challenges, points out that '[c] ases of conflicts of interest over the sea are increasing. There is a growing risk of incidents at sea and of possible escalation into unexpected situations.' ${ }^{68}$

\section{Maritime Security and the Area: A Non-State-Centric Focus}

Contemporary discourse of maritime security seems to be increasingly focused on threats by non-State actors in the maritime domain. This section would explore three possible future security threats by non-State actors with regard to the Area as an important maritime domain, perhaps more so when the actual exploitation in the Area begins, namely: piracy against production support vessels (4.1), maritime terrorism (4.2) and environmental security (4.3) ${ }^{69}$

\subsection{Piracy against Ships and Production Support Vessels (PSVs)}

A critical aspect of deep seabed mining is the use of vessels, ranging from state of the art multipurpose research vessels to Production Support Vessels (PSVs). One of the commonly indicated method of mining operations from available technology and data mining operations in the Area is the use of autonomous underwater vehicles (AUVs), which would be used to survey the seabed prior to extraction, and also remotely operated vehicles (ROVs) that play a role not only in obtaining samples of deposits, but could also be used in mining itself passing resources extracted from the Area through a steel riser pipe (a riser lift system) to a PSV situated on the high seas..$^{70}$ It is important to note that ships

67 Indian Maritime Security Strategy 2015, https://www.indiannavy.nic.in/sites/default/ files/Indian_Maritime_Security_Strategy_Document_25Janı.pdf.

68 National Security Strategy of Japan 2013, p. 5, para.1(4), http://www.cas.go.jp/jp/siryou/ 131217anzenhoshou/pamphlet_en.pdf.

69 The DSM industry is currently at the exploration stage, however, the ISA has already begun work on drafting the Exploitation Mining Code. See https://www.isa.org.jm/legal-ins truments/ongoing-development-regulations-exploitation-mineral-resources-area.

70 See Anon., 'Nautilus sets out its deep sea mining stall,' The Naval Architect, February 2016, http://www.rina.org.uk/Nautilus_sets_out_its_deep_sea_mining_stall.html which mentions a newer innovation of the PSv, the Production Support and Storage Vessel (Pssv). It states that 'the PSSV is an innovative design as the vessel and its mining system are the first of their kind in the world. The ultra-deep water mining process begins at the seafloor where three large mining Rov's cut rock and turn it into slurry for pumping. The slurry is pumped to the PSSV via a Subsea Slurry Lift Pump (SSLP) through a top tensioned riser. At the Pssv the slurry is delivered to a Dewatering Plant (DWP) and then into the vessels' holds for storage. The stoned ore is reclaimed from the ship's holds and offloaded via a 
and Psvs play an important role in deep seabed mining in the Area. The ITLOS Seabed Chambers in its first advisory opinion in response to questions formulated by the Council of the ISA in making a distinction between transportation that should be regarded as 'activities in the Area' and that which would not clearly highlights this. ${ }^{71}$ According to the Chambers:

Transportation to points on land from part of the high seas superjacent to the part of the Area in which the contractor operates cannot be included in the notion of "activities in the Area", as it would be incompatible with the exclusion of transportation from "activities in the Area" in Annex IV, article I, paragraph I, of the Convention. However, transportation within that part of the high seas, when directly connected with extraction and lifting, should be included in activities in the Area. In the case of polymetallic nodules, this applies, for instance, to transportation between the ship or installation where the evacuation of water and the preliminary separation and disposal of material to be discarded take place. The inclusion of transportation to points on land could create an unnecessary conflict with provisions of the Convention such as those that concern navigation on the high seas. ${ }^{72}$

With research ships and Psvs having to operate in the high seas to conduct deep seabed mining research or to facilitate seabed mining, as the case may be, there is the risk of piratical attacks on these vessels. The LOSC states that: ${ }^{73}$

[p] iracy consists of the following acts:

(a) any illegal acts of violence or detention, or any act of depredation, committed for private ends by the crew or the passengers of a private ship or a private aircraft, and directed:

(i) on the high seas, against another ship or aircraft, or against persons or property on board such ship or aircraft;

(ii) against a ship, aircraft, persons or property in a place outside the jurisdiction of any State.

It also includes the act of voluntarily participating in the operation of a ship or aircraft with the knowledge that these are being used for acts of piracy, as

cargo handling system into a bulk carrier moored alongside. The bulk carrier then tranships the ore to market.'

71 Responsibilities and Obligations of States with Respect to Activities in the Area, ITLOS Advisory Opinion No. 17 of 2011.

72 Ibid at para.96.

73 Art.101(a) of LOSC 1982(identical to Art.15(1) of the High Seas Convention 1958). 
mentioned in the definition above, as well as any 'act of inciting or of intentionally facilitating an act of piracy,' as described above. ${ }^{74}$ Due to what is perceived as the heinous nature of piracy it is said that there is universal jurisdiction over the crime..$^{75}$ Although, in theory it is easy to discern what piracy is from the definition provided in the LOSC, in reality it may sometimes be contested. There are debatable issues that arise from the definition of piracy that scholars have engaged with. ${ }^{76}$ However, it is unlikely, for instance, that acts of violence against a vessel engaged in deep seabed mining activities by a vessel with environmental protesters would be regarded as piracy. ${ }^{77}$ Nonetheless, there may be other liability issues that may arise from this, such as criminal or civil damage to property or person.

Currently, there are incidents of piracy in Asia (various seas in Asia), off the coast of Somalia (Indian Ocean) and the Gulf of Guinea, off the West African Coast (Atlantic Ocean), with piratical acts involving petty theft, hijacking of vessels and kidnapping of crew in vessels, as well as well as violent acts of robbery, sometimes accompanied by resource theft. ${ }^{78}$ These various regions have adopted instruments clearly indicating that piracy is a major maritime threat and a present maritime security concern. ${ }^{79}$ Some of these regions, such as the Indian and Atlantic Oceans, have deep seabed mining sites. ${ }^{80}$

A stimulating issue is whether a PSV or submersibles, such as the AUVs and Rovs, used for deep seabed mining, may be regarded as ships for the purposes of Article 101 of the LOSC? In an article on the application of maritime concepts to seabed mining, Spicer and L'Esperance, evaluated whether sea bed mining vessels and submersibles would qualify as 'ships.' ${ }^{81}$ They indicated that

$74 \quad$ Art.101(b) and (c) of LOSC.

75 Art.105 of the Losc. Also see E. Kontorovich and S. Art, "An Empirical Examination of Universal Jurisdiction for Piracy," American Journal of International Law (2010:104), 436-453.

76 See R.Churchill, “The Piracy Provisions of the UN Convention on the Law of the Sea - Fit for Purpose?" In P. Koutrakos \& A. Skordas (eds.) The Law and Practice of Piracy at Sea: European and International Perspectives. (Oxford and Portland, Oregon: Hart Publishing, 2014), pp. 9-32 for interesting and insightful analysis of the problems with defining piracy. See In the Matter of the Artic Sunrise Arbitration (The Kingdom of the Netherlands v. The Russian Federation, (Award on Merits), PCA Case No 2014-02, https://pcacases.com/web/ sendAttach/1438.

78 See Egede, 'Piracy and the East African Region' in P. Koutrakos, \& A. Skordas (eds.), op.cit. 249 at $255^{-257 .}$

79 See note 18 above.

8o See ISA Contractor areas, https://www.isa.org.jm/deep-seabed-minerals-contractors/ overview.

81 W. Spicer and P. L'Esperance, 'Seabed Mining and the application of Maritime Law Concepts', LawyersIssue, July 11, 2016, http://www.lawyerissue.com/seabed-mining-and -the-application-of-maritime-law-concepts/. 
a quick survey of the rather voluminous legislation and case law of certain States would appear to suggest that for an object to be a ship it must satisfy the following requirements: partial navigational use; navigational capabilities; navigation through or above water; vessel under construction and that the mode of propulsion is irrelevant. ${ }^{82}$ They then suggested that the PSV may satisfy many of the common elements of ships, especially when they are independently navigating between extraction sites. They were, however, rather skeptical on whether PSVs permanently moored or positioned to engage in DSM activities for extended period of time would be regarded as a ship. Further, they take the view that the status of AUvs and Rovs as ships is rather ambiguous. ${ }^{83}$ This would need more clarity. If we are to accept the position of Spicer and L'Esperance on PSVs, an attack on a PSV would only be piracy when such PSV qualifies as 'ships.'

\subsection{Maritime Terrorism}

Another risk to ships and PSVs engaged in DSM activities is maritime terrorism. The United Nations, as far back as 1988, had adopted The Convention for the Suppression of Unlawful Acts against the Safety of Maritime Navigation 1988, and the subsequent Protocols, as one of its sectoral Conventions to counter terrorism. ${ }^{84}$ This Convention criminalises attacks against vessels beyond the outer limits of the territorial sea of States which may involve acts such as, a person or group of persons seizing or exercising control over a ship by force or threat of such force; the committing of acts of violence against individuals on a ship or destroys such ship or causes damage to such ship or its cargo. ${ }^{85}$ In recent times, a series of incidents occurred, such as the failed attack on uss The Sullivans in January 2000, or the successful attacks on the uss Cole in October 2000, and the French supertanker, MV Limburg in October, 2002, Superferry 14 just outside Manilla Bay in the Philippines in 2004. As a result, efforts have focused on addressing the issue of terrorist attacks on ships and installations at sea, by upgrading maritime terrorism to a major maritime security threat. ${ }^{86}$ The possibility of such attacks against vessels engaged in DSM could therefore not be ignored.

\footnotetext{
82 Ibid at p. 4 .

83 Ibid.

84 Preamble 3 states that the Convention was a response to 'world-wide escalation of acts of terrorism in all of its forms.'

85 Art.3.

86 See for instance, Art. v(d) of the EU Maritime Security Strategy 2014; Indian Maritime Security Strategy 2015 at pp. 38-39 and Part X of the 2050 Africa's Integrated Maritime Strategy, 2014.
} 
Furthermore, especially since the $9 / 11$ terrorist attack against the USA, there have been concerns about terrorist groups having access to nuclear weapons and other types of WMDs. ${ }^{87}$ The Seabed Control Treaty, as mentioned above, as a State-centric treaty, does not in any way cover the possibility of non-State actors emplacing nuclear weapons or other WMD in the seabed, including the Area. Article 1(1) of the Seabed Control Treaty declares that ' $t$ the States Parties to this Treaty undertake not to emplant or emplace ..., while Article 1(2) says that ' $[\mathrm{t}]$ he States Parties to this Treaty undertake not to assist, encourage or induce any State to carry out activities referred to in paragraph 1 ...', thereby effectively excluding non-State actors, such as terrorist groups from the ambit of the Convention. As a response, the United Nations Security Council resolutions, such as resolutions 1540 and $1887,{ }^{88}$ as well as the Convention for the Suppression of Acts of Nuclear Terrorism 2005, have sought to fill this gap.

\subsection{Environmental Security}

One of the key risks of deep seabed mining is the chance of it having serious adverse impacts on the marine environment. According to Greenpeace, deep seabed mining is likely to cause serious environmental damage that may destroy vital habitats and could lead to the killing of marine life, including the extinction of certain unique species, as well as potentially generating toxic sediments that could contaminate the food chain. ${ }^{89}$ These environmental concerns have been described at various times as a 'new Ocean threat,' 90 'an emerging threat to our Oceans, ${ }^{91}$ 'a global threat to our Oceans', ${ }^{92}$ 'a serious

87 See the testimony of George Tenet before the US Senate Select Committee on Intelligence, 'The Worldwide Threat 2004: Challenges in a Changing Global Context,' 24 February 2004, http://www.nti.org/media/pdfs/10.pdf?_=1316466791.

88 UNSC Resolution 1540(2004) and Resolution 1887(2009).

89 See Indian Ocean Observatory, 'Deep seabed mining will cause serious environmental damage' - Greenpeace', March 10, 2016, http://www.theioo.com/index.php/en/insight/ item/486-deep-seabed-mining-will-cause-serious-environmental-damage-greenpeace See also, Michelle Allsopp, Clare Miller, Rebecca Atkins, Steve Rocliffe, Imogen Tabor, David Santillo \& Paul Johnson, 'Review of the Current State of Development and Potential for Environment Impacts of Seabed Mining Operations,' http://www.greenpeace.to/ greenpeace/wp-content/uploads/2013/o7/seabed-mining-tech-review-2013.pdf.

9o Richard Steiner, 'Deep Sea Mining a New Ocean Threat' The Huffington Post, 20 October, 2016, http://www.huffingtonpost.com/richard-steiner/deep-sea-mining-new -threa_b_8334428.html.

91 Greenpeace, 'Deep seabed mining: an emerging threat to our oceans', 31 July 2013, http:// www.greenpeace.org/international/en/news/Blogs/makingwaves/Deep-seabed-mining/ blog/46110/.

92 WwF South Africa, 'Seabed Mining a global threat to our Oceans: International Contexts', http://awsassets.wwf.org.za/downloads/sosc_factsheet3_web.pdf. 
threat to the stability of Oceans systems and processes' ${ }^{\prime 3}$ and 'next frontier of maritime insecurity.'94

With the protection of the environment increasingly becoming an issue foremost on the agenda of the international community, there is a growing interest in environmental security since the end of the Cold War. Although, the concept of environmental security is essentially a contested one, the academic literature is steadily engaging with the notion that there is some kind of linkage between the environment and security, and the extent to which environmental degradation may be regarded as a security threat. ${ }^{95}$

As far back as 1990, the United Nations Secretary-General stated that: 'ecological threats to the marine environment are also increasingly seen as a more serious threat to national security. ${ }^{\prime 96}$ Also, the United Nations Secretary-General High Level Panel 2004 Report on Threats, Challenge and Change identified some crucial linkages between environmental degradation and security. ${ }^{97}$ While the linkage between environmental degradation and security may be easier to discern when such degradation arises from military activities of State actors, for instance, in the case of the Area, the possibility of a nuclear disaster as a result of military activities by nuclear submarines in the seabed, it is sometimes difficult to fathom such linkages when the degradation is caused by the activities of non-State actors. For instance, NATO in recognition of the possibility of environmental security threats arising from military activities states that: 'the Alliance is working to reduce the environmental effects of military activities and to respond to security challenges emanating from the environment. ${ }^{\prime 98}$ But, even at that, the NATO, in explaining environmental security, appears to recognise that its remit, in this regard, may actually go beyond the direct impact of military activities on the environment, to engaging with certain environmental issues that may have an indirect effect on security by stating:

93 Sylvia Earle, 'Deep Seabed Mining: An Invisible Land Grab', July 20, 2016, https://www .mission-blue.org/2016/o7/deep-sea-mining-an-invisible-land-grab/.

94 Maurice Beseng, 'Will deep sea mining be the next frontier of maritime insecurity in Africa?' July 12, 2016, http://www.maritimesecurity.global/2016/07/12/deep-sea-mining/.

95 Nina Græger, "Environmental Security?" (1996)33(1) Journal of Peace Research, pp. 109-116 and Karen Hulme, "Environmental Security: Implications for International Law,"(2009)19(1) Yearbook of International Environmental Law, pp. 3-26.

96 Para.36, Law of the Sea, Report of the Secretary-General, Doc. A/45/721 \& Coor.1 of 19 November 1990. See also NILOS, International Organizations and the Law of the Sea, Documentary Yearbook, Vol.6, (London, Martinus Nijhoff, 1990), pp. 70-114 at 79.

97 Section III, Paras.53-55, UNGA Doc.A/59/565 of 2 December 2004, https://documents -dds-ny.un.org/doc/UNDOC/GEN/No4/602/31/PDF/No460231.pdf?OpenElement.

98 ENVIRONMENT - NATO'S STAKE, http://www.nato.int/cps/en/natohq/topics_91048 .htm. 
Based on a broad definition of security that recognizes the importance of political, economic, social and environmental factors, NATO is addressing security challenges emanating from the environment. This includes extreme weather conditions, depletion of natural resources, pollution and so on - factors that can ultimately lead to disaster, regional tensions and violence. The Alliance is looking closely at how to best address environmental risks to security in general as well as those that directly impact military activities. ${ }^{99}$

However, more and more there has been a push to see environmental security as going beyond the limited prism of its linkage with military activities. Some scholars, such as Barnett, adopt a broader notion of environmental (in)security by linking environmental degradation with human security. ${ }^{100} \mathrm{He}$ explains environmental (in)security as follows:

Environmental insecurity is defined here as the vulnerability of people to the effects of environmental degradation. So environmental insecurity is more than the physical processes of environmental degradation; it includes the way this degradation affects the welfare of human beings ... Environmental insecurity is very much about risk. In the first instance, a risk to biosphere integrity entails risks to human health. ${ }^{101}$

Hulme points out that the broadest definition of environmental security would include 'man's ability to impact the stability and viability of the biosphere.'102

Even recently, we see that maritime security strategy instruments include the environmental issues, although the latter do not necessarily link directly to military activities, but become indirectly a vital maritime security challenge. ${ }^{103}$ Some of these strategy instruments provisions are broadly framed to also regard environmental degradation by non-State actors in the relevant maritime zone as a maritime security threat. For instance, the European Union Maritime Strategy 2014, includes as part of maritime security risks and threats, environmental risks, which it relates to: the 'unsustainable and unauthorized exploitation of natural and marine resources, threats to biodiversity, IUU fishing, environmental degradation due to illegal or accidental discharge,

99 Environmental Security, Ibid.

100 J. Barnett, The Meaning of Environmental Security: Ecological Politics and Policy in the New Security Era, (London, Zed Publishers, 2001).

101 Ibid at p. 17.

102 Hulme, 'Environmental Security: Implications for International Law, op.cit. at p. 9.

103 See for instance, Art. V(g) of the EU Maritime Security Strategy 2014 and Part XI of the 2050 Africa's Integrated Maritime Strategy 2014. 
chemical, biological and nuclear pollution, in particular sea-dumped chemical munitions and unexploded ordnance.'104

As a result of the possibility of serious environmental impacts due to deep seabed mining, the protection of the environment is high on the agenda of the ISA and it is taking steps to minimize and manage the environmental risks of DSM. ${ }^{105}$ As an illustration, the first advisory opinion of the ITLOS Seabed Disputes Chambers on the Responsibilities and obligations of States sponsoring persons and entities with respect to activities in the Area was mainly devoted to engaging with the extent of sponsoring States' obligation under LOSC 1982 for the protection of the environment as regard DSM activities by contractors sponsored by such States. ${ }^{106}$ These contractors, including not only State entities, but also private commercial entities, such as Multinational Corporations. ${ }^{107}$ As a matter of fact the Chambers in this advisory opinion sets the highest standards of due diligence and goes ahead to endorse a legal obligation to apply the precautionary approach, best environmental practices, and Environmental Impact Assessment (EIA). ${ }^{108}$ Thus environmental security is an issue of vital concern as regard the Area.

104 Ibid. This has revised by a 2018 update and action plan which stresses that environmental degradation due to illegal or accidental discharge is a key maritime risks and threat. See https://www.consilium.europa.eu/en/press/press-releases/2018/o6/26/marit ime-security-eu-revises-its-action-plan/.

105 See Arts.139, 145, 209 and 215 of LOSC. Also, the ISA in its recent draft strategic plan for the period 2019-2023 gave the following as its mission statement: 'The mission of the International Seabed Authority is to be the organization through which States Parties organize and control activities in the Area, which is the common heritage of mankind, to promote the orderly, safe and responsible management and development of the resources of the Area for the benefit of mankind as a whole, including through the effective protection of the marine environment and contributing to agreed international objectives and principles, including the Sustainable Development Goals. This will be accomplished by developing and maintaining a comprehensive regulatory mechanism for commercial deep seabed mining that incorporates effective protection of the marine environment and of human health and safety, the equitable sharing of financial and other economic benefits from activities in the Area and allows for fully integrated participation of developing States through knowledge and best practice exchange consistent with the principle of the common heritage of mankind.' See ISBA/24/A/4 of 21 May 2018.

106 ITLOS Advisory Opinion of 1 February 2011, Case No. 17, https://www.itlos.org/cases/ list-of-cases/case-no-17/.

107 See list of contractors, https://www.isa.org.jm/deep-seabed-minerals-contractors.

108 ITLOS Advisory Opinion of 1 February 2011. For analysis of this decision see David Freestone, 'Advisory Opinion of the Seabed Disputes Chamber of International Tribunal for the Law of the Sea on "Responsibilities and Obligations of States Sponsoring Persons and Entities With Respect To Activities in the Area", (2011)15(7) ASIL Insights, https://www.asil.org/insights/volume/15/issue/7/advisory-opinion-seabed-disputes -chamber-international-tribunal-law-sea- 
Maritime security, though a popular buzzword in contemporary times, is a nebulous concept that may mean different things to different people. In practical terms it is a matter that has relevance both in maritime zones within national jurisdiction and that beyond. This chapter has sought to explore key maritime security issues that are of relevance to the Area. It explored maritime security from the State-centric perspective of using the Area for exclusively peaceful purposes, and the variance in interpretation of what this actually means, as well as issues arising from the Seabed Arms Control Treaty framework, and its limitations. In addition, it explored the possibility of sponsoring States tensions with regard to mining sites allocated by the ISA. It further engaged with certain possible non-State centric maritime security future scenarios that the international community may need to take on as time goes on, especially when exploitation actually begins in the Area, such as piratical and terrorist acts against vessels involved in DSM, as well as the issue of environmental security arising from the risk of environment degradation due to DSM activities.

The Area, which has been described as 'a new frontier' for future mineral development and contains extremely valuable mineral resources, is a vital maritime zone that should be kept secure so users of this maritime domain would be protected. This is in line with the Common Heritage of Mankind which emphasizes the peaceful use of this maritime space and the importance of the effective protection of human lives. ${ }^{109}$ ISA, as the international organization charged with the responsibility to 'organize and control activities in the Area,'110 need to start thinking seriously about developing some sort of maritime security strategy as regard the Area to avoid irreparable damages to security interests of States, interested parties and the environment.

109 Arts.141 and 146 of LOSC.

110 Art.157(1) of LOSC. 